\title{
PEMBUANGAN BAYI DALAM PERSPEKTIF PENELANTARAN ANAK
}

Airlangga Justitia

Fakultas Hukum Universitas Airlangga

Email : Airlanggajustitia11@gmail.com

\begin{abstract}
The act of disposing of a newly born child is obviously a criminal offense, since this act does not necessarily reflect the humanism side of the human person. an act which the rule of law is proclaimed as a prohibited act is called a criminal act or it may be referred to as a crime. According to its nature and nature, these criminal acts are unlawful acts. These acts can also harm society, in the sense of contradicting or impeding the implementation of the social order of society that is considered good and fair. There are 3 (three) legal instruments that contain criminal sanctions against the perpetrators of the crime of infant / child disposal namely the Criminal Code, Law No. 23 of 2004 on the Elimination of Domestic Violence, and Law No. 35 of 2014 on Child Protection. However, newly born child abusers are still not eliminated, and one of the factors is the lack of conviction of criminal prosecution.
\end{abstract}

\section{Keyword: Children's Disposal, Child Abandonment, Which causes death, Judge considerations}

\section{Pendahuluan}

Anak merupakan anugerah yang tidak terhingga dari Tuhan Yang Maha Esa (TYME). Bentuk eksistensi manusia sebagai manusia adalah mampu menjaga eksistensinya tersebut, dan salah satu cara untuk menjaga eksistensinya tersebut adalah dengan memiliki keturunan. Keturunan sebagai generasi penerus yang dapat menjaga sekaligus mengangkat eksistensi manusia. Perihal sifatnya dalam cakupan yang lebih luas lagi, keturunan sebagai generasi penerus tersebut menjadi asset yang sangat bernilai bagi suatu kumpulan masyarakat yang hidup dalam 1 (satu) tujuan yang sama yang disebut negara.

Untuk menjaga harmonisasi dan interaksi antara satu individu dengan individu yang lainnya, maka diperlukan suatu instrumen yang dapat mengatur itu semua yang disebut sebagai aturan (hukum). Hukum dapat memberikan perlindungan dari ancaman disharmonisasi dalam suatu kumpulan masyarakat tersebut. Perlindungan hukum yang diimplementasikan dalam ranah penegakkan hukum, merupakan suatu usaha untuk mewujudkan ide-ide dan konsepkonsep menjadi kenyataan. Pendapat Soerjono Soekanto terhadap penegakkan hukum adalah: "secara konseptual, maka inti dan arti penegakkan hukum terletak pada kegiatan menyerasikan hubungan nilai-nilai yang dijabarkan didalam kaidah-kaidah yang baik dan mengejahwantahkan dan sikap tindakan sebagai rangkuman penjabaran nilai tahap akhir, untuk menciptakan, memelihara dan mempertahankan kedamaian pergaulan 
hidup"1. Penegakkan hukum sebagai suatu proses yang pada hakekatnya merupakan diskresi menyangkut pembuatan keputusan yang tidak secara ketat diatur oleh kaidah hukum, akan tetapi mempunyai unsur penilaian pribadi dan pada hakekatnya diskresi berada diantara hukum dan moral.

Terhadap anak, perlindungan hukum lebih diutamakan karena sifat alamiah anak yang cenderung masih belum dapat menjadi pribadi yang seutuhnya menjadi suatu pribadi. Oleh sebab itu perlindungan terhadap bayi bahkan sudah dimulai sejak anak tersebut berada dalam kandungan. Pasal 2 Burgerlijk Wetboek (BW) yang menyatakan "seorang anak yang masih dalam kandungan ibunya dianggap sebagai subyek hukum sepanjang kepentingan si anak itu menghendakinya" hal ini yang kemudia dikenal dengan istilah fiksi hukum. Undang-Undang Dasar Negara Republik Indonesia Tahun 1945 (UUD NRI 1945) Pasal 28B ayat (2) mengatakan: "setiap anak berhak atas kelangsungan hidup dan berkembang serta berhak atas perlindungan dari kekerasan dan diskriminasi", dalam hal ini termasuk bayi.

\section{Perserikatan Bangsa-Bangsa}

(PBB) melalui Majelis Umum juga telah mengeluarkan suatu deklarasi yakni Declaration of the Rights of the Child dengan resolusi Majelis Umum 1386 (XIV)

${ }^{1}$ Soekanto. S. (1983) Faktor-Faktor Yang Mempengaruhi Penegakkan Hukum. Jakarta : Raja Grafindo Persada. Hlm 5. tanggal 30 November 1959 yang berisikan 10 (sepuluh) prinsip, serta suatu konvensi yakni Convention on the Rights of the Child sesuai resolusi Majelis Umum PBB 44/45 tanggal 20 November 1989. Sejumlah instrumen internasional HAM tersebut, baik DUHAM maupun Deklarasi Hak-hak Anak tidak diratifikasi oleh Indonesia, sedangkan Konvensi Hak-hak Anak diratifikasi oleh Indonesia berdasarkan Keputusan Presiden (Keppres) No. 36 Tahun 1990, sehingga tingkatan peraturan perundangan berbentuk Keppres ini sangat rendah, bahkan tidak dikenal sebagai salah satu jenis peraturan perundang-undangan menurut UndangUndang No. 12 Tahun 2011 tentang Pembentukan Peraturan PerundangUndangan.

Instrumen Internasional HAM yakni Universal Declaration of Human Right (Deklarasi Universal HAM/DUHAM), mengatur sejumlah ketentuan mengenai hak untuk hidup dan hak anak di dalam Pasal 1 bahwa "All human being are born free and equal in dignity and rights. They are endowed with reason and conscience and should act towards one another in a spirit of brotherhood".2 Juga, dalam Pasal 3 bahwa "Everyone has the right to life, liberty and security of person".3 Serta dalam Pasal 25 ayat (2) bahwa "Motherhood and childhood are entitled to special care and assistance. All children, whether born in or wedlock, shall enjoy the same social protection" 
perlindungan hukum terhadap anak tersebut telah menjadi concern dalam setiap perkumpulan masyarakat yang beradab.

Anak yang dalam hukum digolongkan dalam subyek hukum melekat hak-hak dan kewajiban-kewajiban terhadap dirinya. Dalam pembahasan kali ini hak-hak nya lah yang lebih diutamakan untuk dipenuhi karena anak sudah pasti belum cakap hukum untuk dikenakan suatu kewajiban hukum, namun tidak meniadakan pengertian anak sebagai suatu subyek hukum (natuurlijke persoon). Tidak ada atau belum adanya peraturan perundang-undangan khusus yang mengatur tentang bayi menjadikan dalam pebahasan kali ini bayi tersebut dianggap sama dengan anak (karena memiliki persamaan konsep yaitu sama-sama belum dewasa). Dengan demikian segala peraturan perundang-undangan yang mengatur mengenai anak dapat pula dipakai kepada bayi dalam setiap hak-hak dan kewajiban yang melekat padanya.

Undang-undang Nomor 4 Tahun 1979 tentang Kesejahteraan Anak, Pasal 2 ayat (1) sampai ayat (4) menyatakan:

1) Anak berhak atas kesejahteraan, perawatan, asuhan dan bimbingan berdasarkan kasih sayang baik dalam keluarganya maupun di dalam asuhan khusus untuk tumbuh dan berkembang dengan wajar;

2) Anak berhak atas pelayanan untuk mengembangkan kemampuan dan kehidupan sosialnya, sesuai dengan kebudayaan dan kepribadian bangsa, untuk menjadi warga negara yang baik dan berguna;

3) Anak berhak atas pemeliharaan dan perlindungan, baik semasa dalam kanudngan maupun dilahirkan

4) Anak berhak atas perlindungan terhadap lingkungan hidup yang dapat membahayakan atau menghambat pertumbuhan dan perkembangannya dengan wajar.

Pembuangan anak merupakan perbuatan yang sangat menciderai sisi kemanusiaan dan moral terkait dengan norma-norma yang ada, terlebih lagi perbuatan pembuangan bayi tersebut adalah merupakan suatu tindak pidana.

Jika pembuangan anak dilakukan dalam keadaan masih hidup, dan dilakukan oleh orang tua yang dalam hal ini adaah ibunya yang membuang anak tersebut setelah dilahirkan, maka ancaman pidana terkait hal ini terdapat dalam Pasal 308 KUHP: “Jika seorang ibu karena takut akan diketahui orang tentang kelahiran anaknya, tidak lama sesudah melahirkan, menempatkan anaknya untuk ditemukan atau meninggalkannya dengan maksud untuk melepaskan diri daripadanya, maka maksimum pidana tersebut dalam Pasal 305 dan 306 dikurangi setengah (1/2)". Adapun Pasal 305 KUHP memberikan aturan mengenai menaruh/menempatkan anak di bawah umur 
7 (tujuh) tahun (termasuk juga bayi) di suatu tempat agar dipungut orang lain dengan maksud terbebas dari pemeliharaan anak itu, dipidana selama 5 (lima) tahun 6 (enam) bulan, sedangkan pemberatan terhadap hal ini yang berdampak kepada si Anak mengalami luka berat sesuai ketentuan Pasal 306 ayat (1) KUHP adalah 7 (tujuh) tahun 6 (enam) bulan, dan akan diperberat apabila dalam hal melakukan pembuangan bayi tersebut menyebabkan kematian pada diri bayi dipidana dengan pidana penjara selama 9 (sembilan) tahun. Juga melanggar Pasal 341 KUHP, Pasal 342 KUHP serta merupakan pelanggaran terhadap UndangUndang Nomor 39 Tahun 1999 tentang Hak Asasi Manusia berkaitan dengan hak anak dimana anak sejak masih dalam kandungan (janin) berhak untuk hidup dan mempertahankan kehidupannya.

Sebagai contoh kasus dapat dikaji dalam Putusan Pengadilan Negeri Lumajang Nomor 600/Pid.B/2011/PN.Lmj yang Terdakwa telah membuang seorang anak berjenis kelamin laki-laki dalam sebuah tas yang merupakan anak kandung terdakwa sendiri. Kemudian Terdakwa meletakkan tas tersebut di pinggir jalan, terdakwa melakukan perbuatan tersebut karena takut diketahui oleh orang lain kalau terdakwa telah melahirkan seorang anak.

Selanjutnya Putusan Pengadilan Negeri Bondowoso Nomor: 101/PID.SUS/2015/PN.BDW dimana

Terdakwa telah membuang seorang anak yang telah dilahirkannya disungai dengan menempatkan bayi tersebut kedalam tas kresek terbuka dan menyembunyikan anak yang baru dilahirkannya tersebut disela-sela tanaman padi di sawah Desa Pakisan Kecamatan Tlogosari Kabupaten Bondowoso.

Contoh kasus selanjutnya adalah berdasarkan Putusan Pengadilan Negeri Majalengka Nomor: 164/Pid.B/2013/PN.Mj1 atas Terdakwa yang bekerja sebagai Tenaga Kerja Indonesia (TKI) di Arab Saudi yang melakukan pembuangan terhadap anak yang telah dilahirkannya akibat pemerkosaan yang dilakukan oleh majikan Terdakwa selama berada di Arab Saudi. Terdakwa menempatkan anak yang baru dilahirkannya itu kedalam ranjang dan menaruh anak yang baru dilahirkannya tersebut di depan gudang kayu supaya anak terdakwa tersebut ada yang merawatnya.

Beberapa kasus pembuangan anak kebanyakan dilakukan oleh Ibu kandungnya sendiri dan biasanya dilakukan setelah proses melahirkan, karena sebagian besar melakukan hal tersebut karena merasa takut dan khawatir diketahui oleh orang lain bahwa dirinya sedang mengandung dan melahirkan seorang anak. Kejahatan yang dilakukan seorang Ibu terhadap anaknya sendiri dinyatakan sebagai sesuatu yang mustahil terjadi jika tidak ada sebab yang 
bersifat khusus (secreetfactors) ${ }^{2}$. Kasus bayi sebagai pembuangan anak; dan pembuangan anak yang baru dilahirkan lebih Pertimbangan Hakim (Ratio Decidendi) cenderung pada masalah kejiwaan, adanya dalam memutus tindak pidana pembuangan tekanan atau beban pikiran psikologis yang ditanggung seorang Ibu terhadap anak yang dilahirkannya, dan juga masalah lingkungan sosial.

Usaha untuk mencegah dan bahkan dalam hal pemberian efek jera terhadap pelaku tindak pidana pembuangan anak ini adalah dengan menegakkan aturan hukum pidana yang tegas, sehingga dapat tercapainya kepastian hukum yang nantinya akan bermuara pada keadilan. Kepolisian Negara Republik Indonesia sebagai garda terdepan untuk mencegah dan menanggulangi kejahatan yang harus dilaksanakan dengan baik dan penuh rasa tanggung jawab. Terkait tindak pidana pembuangan anak yang baru saja dilahirkan ini, para laki-laki yang sebenarnya "turut serta" dalam proses pembuahan dan kehamilan, selalu lolos dari jerat hukum, atau setidaknya tidak pernah dianggap ikut bertanggungjawab dari perbuatan tersebut, sehingga sudah saatnya Aparat Penegak Hukum (Polisi, Jaksa, Hakim) memberikan efek jera pula kepadanya. ${ }^{3}$ Permasalahan yang diangkat dalam tulisan ini adalah terkait Perbedaan konsep pembuangan bayi sebagai penelantaran anak dan konsep pembuangan

${ }^{2}$ Sumiyanto. (2000). Pembunuhan Bayi Oleh Ibu Kandungnya Sendiri, Malang : Laporan Hasil Penelitian Universitas Brawijaya. Hlm 24.

${ }^{3}$ Rahardjo S. (2002) Polri Sipil dan Perubahan Sosial di Indonesia. Jakarta : Kompas. Hlm 45.

anak dan penelantaran anak dalam perspektif penelantaran anak.

\section{Metode Penelitian}

Tipe penelitian yang digunakan adalah tipe penelitian normatif. Pemilihan penelitian hukum (legal research) ini dilakukan dengan metode sesuai dengan karakter yang khas dari ilmu hukum (jurisprudence) yang berberda dengan metode dalam ilmu sosial (social science) atau metode dalam ilmu alam (natural science). ${ }^{4}$ Penelitian hukum normatif yakni suatu penelitian yang terutama mengkaji ketentuan-ketentuan hukum positif maupun asas-asas hukum dengan melakukan penjelasan secara sistematis ketentuan hukum dalam sebuah kategori hukum tertentu, menganalisis hubungan antara ketentuan hukum, menjelaskan dan memprediksi pengembangan hukum ke depan. ${ }^{5}$ Menurut Terry Hutchinson, penelitian ini termasuk dalam kategori doctrinal research yaitu yuridis (technicsjuridich), filsafat, asas dan pada tataran teori hukum research which provides a systematic exposition of the rules governing a particular legal category, analyses the relationtip between rules,

\footnotetext{
${ }^{4}$ Bruggink J.J.H. (1995) Rechtsreflecties, terjemahan Arief Sidharta. Bandung :Citra Aditya Bakti. Hlm 213-218.

${ }^{5}$ Hadjon. P.M. (1997). Pengkajian Ilmu Hukum. Paper Pelatihan Metode Hukum Normatif. Surabaya : UNAIR.
} 
explains areas of difficulty and, perhaps, predicts future developments. ${ }^{6}$ Penelitian ini tertuju pada tataran ilmu hukum dogmatik dan teori hukum. Pada tataran dogmatik hukum mempersoalkan pengertian dan konsep teknis mempersoalkan konsep umum (algemene begrippen). ${ }^{7}$

\section{Analisis dan Pembahasan}

Perbuatan pembuangan terhadap anak yang baru saja dilahirkan jelas merupakan tindak pidana, karena perbuatan ini sangatlah tidak mencerminkan sisi humanisme dalam manusia itu sendiri. perbuatan yang oleh aturan hukum dinyatakan sebagai perbuatan yang dilarang dinamakan perbuatan pidana maupun dapat disebut juga sebagai delik. Menurut wujud dan sifatnya, perbuatanperbuatan pidana ini adalah perbuatanperbuatan yang melawan hukum. Perbuatanperbuatan ini juga dapat merugikan masyarakat, dalam arti bertentangan dengan atau menghambat akan terlaksananya tata dalam pergaulan masyarakat yang dianggap baik dan adil. ${ }^{8}$

Terdapat instrumen hukum yang mengatur mengenai perbuatan menelantarkan anak yang baru saja dilahirkan ini yang diatur dalam Bab XV

${ }^{6}$ Hutchinson. T. (2002) Researching and Writing in Law, Sidney : Lawbook Co. Hlm 9.

${ }^{7}$ Hadjon. P.M (et. All) (2005). Argumentasi Hukum, Yogyakarta : Gajah Mada University Press. Hlm 1112.

${ }^{8}$ Saleh. R. (1983) Perbuatan Pidana dan Pertanggung Jawaban Pidana (Dua Pengertian Dasar Dalam Hukum Pidana), Jakarta : Aksara Baru Jakarta. Hlm 13.
Buku II KUHP (Kejahatan) mengenai meninggalkan orang yang perlu ditolong. Pasal 304 KUHP $^{9}$ merupakan perbuatan yang dilakukan dengan sengaja menyebabkan atau membiarkan orang lain dalam keadaan sengsara, sedangkan seseorang tersebut wajib memberi kehidupan, perawatan atau pemeliharaan kepada orang itu karena hukum yang berlaku atau karena perjanjian, dalam hal ini orang tua ataupun wali dari anak tersebut.

Pasal 305 KUHP memberikan pengertian bahwa terdapat 2 (tindakan) yang memenuhi unsur pasal tersebut yaitu menelantarkan anak dibawah umur 7 (tujuh) tahun dan meninggalkan anak dengan tujuan melepaskan anak tersebut dari tanggung jawab si pelaku. Perbedaan diantara kedua tindak pidana tersebut adalah apabila seseorang tersebut membuang anak bermakna tindakan tersebut dapat dilakukan oleh siapa saja (setiap orang), sedangkan tindakan untuk melepaskan seorang anak dari tanggung jawab si pelaku sudah pastilah bahwa tindakan tersebut hanya dapat dilakukan oleh seseorang yang memiliki hubungan darah dengan anak yang dibuang tersebut (orang tuanya atau dapat pula wali anak).

Apabila yang menelantarkan anak tersebut adalah orang tuanya, hal ini diperberat secara sanksi pidananya semakin diperberat yaitu ditambah dengan 1/3

\footnotetext{
${ }^{9}$ R. Soesilo. Loc. Cit. Hlm 223.
} 
(sepertiga)nya sebagaimana diatur dalam ketentuan Pasal 307 KUHP. Terdapat pula instrumen hukum lain yang mengatur terkait hal ini diluar KUHP yaitu dalam UndangUndang Nomor 23 Tahun 2004 Tentang Penghapusan Kekerasan Dalam Rumah Tangga. Dalam pengaturan undang-undang tersebut perbuatan penelantaran anak dapat dikenakan Pasal 9 ayat (1) jo. Pasal 49 huruf a Undang-Undang Nomor 23 Tahun 2004 Tentang Penghapusan Kekerasan Dalam Rumah Tangga yang mengatur.

Perbuatan penelantaran anak yang menyebabkan kematian yang dilakukan oleh orang tuanya (ibunya) dalam hal ini dapat masuk kedalam kategori pembunuhan berencana sebagaimana dimaksud dalam Pasal 340 KUHP. Rumusan Pasal 340 KUHP ini sebenarnya sama dengan Pasal 338 KUHP yakni memiliki persamaan merupakn suatu tindak pidana menghilangkan nyawa orang lain. Perbedaan Pasal 340 KUHP dengan Pasal 338 KUHP (pembunuhan dengan sengaja) adalah unsur berencana (met voorbedache rade). Menurut Tirtaamidjaja, didalam unsur berencana ini terdapat jangka waktu yang panjang atau pendek antara keputusan dan pelaksanaannya bukan merupakan suatu kriteria bagi "pembunuhan berencana", tatapi jangka waktu itu harus ada untuk menetapkan apakah orang yang melakukan tindak pidana itu setelah ada dalam keadaan dapat berfikir telah memikirkan arti dan akibat-akibat dari perbuatan yang dimaksudkan itu. ${ }^{10}$

Dalam perbuatan menghilangkan nyawa orang lain (dalam hal ini pembunuhan terhadap anak) terdapat 3 (tiga) syarat yang harus dipenuhi yakni: Pertama, adanya wujud perbuatan; Kedua, adanya suatu kematian (orang lain); Ketiga, Adanya hubungan sebab dan akibat (casual verband) antara perbuatan dan akibat kematian orang lain. ${ }^{11}$ Mengenai menghilangkan nyawa secara berencana bagi anak (kindermoord), adanya pendapat yang mengatakan bahwa unsur dengan rencana terlebih dahulu adalah bukan karena bentuk kesengajaannya, tetapi berupa cara membentuk kesengajaan/opzet tersebut yang mencakup 3 (tiga) syarat antara lain:

1. Opzet nya itu dibentuk setelah direncanakan terlebih dahulu;

2. Setelah orang merencanakan opzet nya tersebut, maka yang penting adalah cara opzet tersebut dibentuk yaitu harus dalam keadaan yang tenang;

3. Dan pada umumnya, merencanakan pelaksanaan opzet itu memerlukan jangka waktu yang agak lama. ${ }^{12}$

\footnotetext{
${ }^{10}$ Tongat. (2003) Hukum Pidana Materiil Tinjauan Atas Tindak Pidana Terhadap Subyek Hukum Dalam Kitab Undang-Undang Hukum Pidana. Jakarta : Djambatan, HIm 3.

${ }^{11}$ Lamintang P.A.F. (1985) Delik-Delik Khusus Kejahatan Terhadap Nyawa, Tubuh yang membahayakan bagi tubuh, nyawa. Bandung : Bina Cipta. Hlm 95.

${ }^{12}$ Sianturi S. R. (1983) Tindak Pidana Di KUHP Berikut Uraiannya. Bandung : Alumni. Hlm 64.
} 
Berbagai kasus yang terjadi mengenai penelantaran anak yang menyebabkan matinya anak ini dilakukan dalam keadaan yang sangat tergesa-gesa dan dapat dikatakan dilakukan dengan keadaan yang sangat cepat (dlam pelaksanaanya). Akan tetapi menurut Andi Hamzah hal ini tidak menghilangkan unsur berencana itu sendiri, Andi Hamzah berpendapat bahwa unsur berencana itu adalah adanya keadaan hati untuk melakukan pembunuhan, walaupun keputusan yang diambil dalam hati itu sekejap saja dengan pelaksanaannya. $^{13}$ Hoge Raad dalam Putusannya tanggal 2 Desember 1940, N.J 1941 No. 293 menyatakan “.... dengan berpikir tenang dan menimbang dengan tenang..." merupakan penentu diterapkannya Pasal 340 KUHP. Hal ini mengenai tindak pidana pembuangan anak yang menyebabkan matinya anak diatur pula dalam Pasal 341 KUHP dan Pasal 34 KUHP.

\section{Pasal 341 KUHP:}

"Seorang ibu yang karena takut akan diketahui bahwa ia melahirkan anak dengan sengaja menghilangkan nyawa anaknya pada saat anak itu dilahirkan atau tidak lama kemudian, diancam karena membunuh anak sendiri, dengan pidana penjara paling lama 7 (tujuh) tahun (KUHP 37-1 Sub 2, Pasal 308, Pasal 338, Pasal 342, dst., Pasal 487)."

\footnotetext{
${ }^{13}$ Koeswadji. H.H, (1984) Kejahatan Terhadap Nyawa, Asas-Asas Kasus dan Permasalahannya. Surabaya : Sinar Widjaya. Hlm 41.
}

Adapun rumusan Pasal 341 KUHP itu dirinci, maka terdiri dari unsur-unsur sebagai berikut:

\section{Unsur Objektif}

a) Pelaku adalah seorang ibu;

b) Perbuatannya menghilangkan nyawa orang lain;

c) Objeknya adalah nyawa bayinya sendiri;

d) Waktunya;

e) Pada saat bayi tersebut dilahirkan;

f) Motifnya karena takut diketahui telah melahirkan;

\section{Unsur Subyektif}

a) Dengan sengaja

Unsur kesengajaan dalam pembunuhan bayi harus ditunjukkan pada seluruh unsur yang ada dibelakangnya. Nahwa dengan demikian, maka kehendak dan apa yang diketahui si ibu ditunjukkan yakni:

a) Untuk mewujudkan perbuatan menghilangkan nyawa;

b) Nyawa bayinya sendiri;

c) Waktunya, yakni: ketika bayi sedang dilahirkan, dan tidak lama setelah bayi dilahirkan.

Artinya, kesengajaan yang demikian itu adalah, bahwa si ibu menghendaki mewujudkan perbuatan menghilangkan nyawa dan mengetahui perbuatan itu dapat menimbulkan akibat kematian, yang diketahuinya perbuatan mana dilakukan pada saat dilahirkan atau tidak lama setelah 
dilahirkan atau tidak lama setelah

dilahirkan. ${ }^{14}$ Pembunuhan bayi berencana

(kindermoord) tersebut mempunyai unsurunsur sebagai berikut:

1. Pelaku adalah seorang ibu kandungnya;

2. Adanya putusan kehendak yang telah diambil sebelumnya;

3. Perbuatannya menghilangkan nyawa;

4. Objek nyawa adalah bayi kandungnya sendiri;

5. Waktu (pada saat bayi dilahirkan, tidak lama setelah bayi dilahirkan).

Selain itu mengenai instrumen hukum yang mengatur mengenai perbuatan penelantaran anak yang baru saja dilahirkan dalam perspektif penelantaran anak juga diatur dalam Pasal 76B Undang-Undang Nomor 35 Tahun 2014 Tentang Perubahan Kedua Atas Undang-Undang Nomor 23 Tahun 2002 Tentang Perlindungan Anak.

Perihal kebijakan hukum pidana terkait penelantaran anak yaitu sebelum adanya undang-undang yang khusus mengatur tindak pidana terkait penelantaran anak, pelaku tindak pidana terkait penelantaran anak masih dikenakan ketentuan dalam KUHP. Namun dengan adanya asas perundang-undangan yaitu asas lex specialis derogat legi generalis yang berarti aturan hukum yang bersifat khusus mengesampingkan aturan hukum yang lebih

\footnotetext{
${ }^{14}$ Mangare. P. (2016) Kajian Hukum Tindak Pidana Pembunuhan Anak Oleh Ibu Kandungnya (Menurut Pasal 134 KUHP), Jurnal Hukum Lex Privatum, Volume IV. Nomor 2. Hlm 89.
}

umum, maka setelah adanya undang-undang yang mengatur tindak pidana terkait penelantaran anak seperti Undang-Undang Nomor 23 Tahun 2004 maupun UndangUndang Nomor 35 Tahun 2014.

Konsep Perlindungan Hukum merupakan salah satu hal yang sangat penting untuk dibahas, karena fokus kajian teori ini pada perlindungan hukum yang diberikan kepada masyarakat. Masyarakat yang menjadi sasaran pada teori ini adalah masyarakat yang berada pada posisi lemah, baik dari segi ekonomi maupun dari aspek yuridisnya. ${ }^{15}$ Masyarakat tersebut salah satunya adalah anak. Perlindungan hukum dalam hal ini lebih mengarah kepada salah satu tujuan hukum yang hendak dicapai dalam tataran berbangsa dan bernegara, yaitu: keadilan.

Pembuangan anak yang baru saja dilahirkan yang menyebabkan kematian bagi anak tersebut dapat pula disebut sebagai pembunuhan anak/bayi (infanticide). Merupakan istilah hukum yang menggambarkan tentang pembunuhan anak dengan usia di bawah 1 (satu) tahun oleh ibu si anak. Sedangkan menurut Infanticide Act 1938, Article I (London) adalah: adalah di mana seorang wanita dengan sengaja atau karena kelalaiannya mengakibatkan kematian atas anaknya yang berumur di bawah 12 (dua belas) bulan. Namun pada

\footnotetext{
${ }^{15}$ Salim HS. (2013) Penerapan Teori Hukum Pada Penelitian Tesis dan Disertasi. Jakarta : Raja Grafindo Persada. Hlm 259.
} 
saat tindakan ataupun kelalaiannya tersebut terjadi, didapatkan gangguan mental dikarenakan oleh alasan belum pulihnya efek dari kelahiran anaknya, atau efek dari menyusui sebagai konsekuensi melahirkan anak tanpa perkecualian. Hal tersebut dapat dinyatakan sebagai pembunuhan, dan dinyatakan bersalah sebagai infanticide. ${ }^{16}$

Sebagaimana telah dijelaskan sebelumnya, pengaturan hukum terkait tindak pidana pembuangan anak ini terdapat dan tersebar dalam berbagai peraturan perundang-undangan yang ada. Beberapa instrumen hukum tersebut mengatur mengenai norma pidananya begitupula mengenai sanksi pidana yang diatur secara berbeda-beda. KUHP mengatur sanksi yang dapat dijatuhkan untuk pelaku pembuangan bayi/anak terdapat dalam ketentuan Pasal 306 KUHP yang mengatur mengenai hukuman tambahan bagi pelaku tindak pidana berdasarkan Pasal 304 KUHP dan Pasal 305 KUHP. Pasal 308 KUHP juga mengatur apabila seorang ibu membuang anaknya tidak lama sesudah anak itu dilahirkan, oleh karena takut akan diketahui orang bahwa ia melahirkan anak, atau jika ia meninggalkan anak itu dengan tujuan melepaskan anak itu daripadanya karena

\footnotetext{
${ }^{16}$ Hadidjah. S. (2008) Penegakkan Hukum Pidana Dalam Penanggulangan Pembunuhan Bayi di Wilayah DIY, Tesis, Fakultas Hukum Universitas Diponegoro Semarang. Hlm 252. Mengutip pendapat dari Spinelli (et all) (2004) Maternal Infanticide Associated With Mental Illness; Prevention and The Promised of Saved Lives America Journal. Hlm 16.
}

takut juga, maka maksimum hukuman atas tindak pidana dari Pasal 305 dan Pasal 306 KUHP, dikurangi sampai seperduanya.

Dalam Pasal 49 huruf a UU No. 23 Tahun 2004 Tentang PKDRT juga mengatur bahwa pelaku yang menelantarkan orang dalam lingkup rumah tangganya, padahal menurut hukum yang berlaku baginya atau karena persetujuan atau perjanjian ia wajib memberikan kehidupan, perawatan, atau pemeliharaan kepada orang tersebut"; dan Pasal 49 huruf a yang berbunyi "Dipidana dengan pidana penjara paling lama 3 (tiga) tahun atau denda paling banyak Rp 15.000.000,00 (lima belas juta rupiah), setiap orang yang: a. Menelantarkan orang lain dalam lingkup rumah tangganya sebagaimana dimaksud dalam Pasal 9 ayat (1)".

Pasal 77B UU Nomor 35 Tahun 2014 Tentang Perlindungan Anak menyatakan "Setiap orang yang melanggar ketentuan sebagaiman dimaksud dalam Pasal 76B, dipidana dengan pidana penjara paling lama 5 (lima) tahun dan/atau denda paling banyak Rp100.000.000,00 (seratus juta rupiah)."

Pasal 77B tersebut memuat hukuman atau sanksi pidana bagi tindak pidana dari Pasal 76B Undang-Undang Nomor 35 Tahun 2014, yaitu berupa pidana penjara paling lama lima tahun dan/atau pidana denda paling banyak seratus juta rupiah.

Dapat diketahui terdapat 3 (tiga) instrumen hukum yang memuat sanksi 
pidana terhadap pelaku tindak pidana masyarakat agar tidak terjadi kembali pembuangan bayi/anak yaitu KUHP, UU No mengenai hal ini.

23 Tahun 2004 Tentang Penghapusan

Kekerasan Dalam Rumah Tangga, dan Undang-Undang Nomor 35 Tahun 2014 Tentang Perlindungan Anak. Diantara sanksi pidana yang terdapat dalam 3 (tiga) instrumen hukum tersebut, sanksi pidana dalam penegakkan hukumnya. Secara garis besar, Konvensi Tentang Hak Anak adalah instrumen yang paling komprehensif yang berlaku untuk saat ini. terdapat setidaknya 4 (empat) poin utama dalam Konvensi Hak Anak tersebut antara lain: (1). Non diskriminasi (Pasal 2); (2). Kepentingan terbaik bagi anak; (3). Hak untuk hidup, kelangsungan hidup dan pengembangan anak; dan (4). Pandangan anak.

Penegak hukum, dan komisi khusus untuk menanggulangi masalah pembunuhan terhadap anak yang baru saja dilahirkan (infanticide) atau bahkan aborsi merupakan langkah yang dapat diwujudkan dikemudian hari. Penegakkan hukum penting untuk lebih bersifat aktif dalam menangani infanticide yang ada agar tidak lagi terulang kembali. Hukum sejatinya perlu memperbaharui mengenai masalah infanticide ini dengan cara yang lebih tajam dalam artian lebih tegas dalam penegakkan hukumnya, sehingga sebuah langkah awal yang diharapkan dan menjadikan ketakutan bagi pelaku (efek jera) ataupun kepada
Terdapat beberapa cara yang dapat digunakan dalam upaya melakukan penanggulangan terhadap kejahatan seperti yang telah dikemukakan oleh G.P. Hoefnagel, bahwa penanggulangan kejahatan itu dapat dilakukan dengan 3 (tiga) cara sebagai berikut: ${ }^{17}$

1. Penerapan hukum pidana (criminal law application);

2. Pencegahan tanpa pidana (prevention without punishment);

3. Mempengaruhi pandangan masyarakat mengenai kejahatan dan pemidanaan lewat media massa (Influencing news of society on crime and punishment/ mass media).

Marc Ancel menyatakan bahwa modern criminal science terdiri dari 3 (tiga) komponen yaitu: Criminology, Criminal law, dan Penal Policy ${ }^{18}$. Penal Policy adalah suatu ilmu sekaligus seni yang pada akhirnya mempunyai tujuan praktis untuk memungkinkan peraturan hukum positif dirumuskan secara lebih baik dan untuk memberi pedoman tidak hanya kepada pembuat undang-undang, tetapi juga kepada pengadilan untuk menerapkan undang-

\footnotetext{
${ }^{17}$ Muladi dan Barda Nawawi Arief, (1998) TeoriTeori dan Kebijakan Pidana. Bandung : Alumni Hlm 48.

${ }^{18}$ Arief B.N. (2005) Beberapa Aspek Kebijakan Penegakkan dan Pengembangan Hukum Pidana, Citra Aditya Bakti, Bandung. Hlm 75.
} 
undang dan juga kepada penyelenggara atau pelaksana putusan pengadilan. ${ }^{19}$

Ratio decideni adalah sebuah istilah yang berasal dari bahasa latin yang sering diterjemahkan secara harfiah sebagai "alasan untuk keputusan itu" (the reason/ the rationale for the decision) Blacks Law Dictionary menyatakan ratio decidendi sebagai "(1). The point in a case which determines the judgement, (2). The principle which the case establishes". ${ }^{20}$ Aspek-aspek pertimbangan-pertimbangan yuridis terhadap suatu tindak pidana yang didakwakan kepada seorang terdakwa dimuka persidangan merupakan konteks yang paling penting dalam suatu putusan hakim. Majelis Hakim dalam menjatuhkan putusan sudah barang tentu memperhatikan berbagai aspek-aspek yang ada demi tegakknya suatu putusan yang berkeadilan bagi semua pihak tanpa terkecuali. Pertimbangan-pertimbangan yuridis dalam putusan hakim pada hakikatnya merupakan pembuktian unsurunsur (bestandellen) dari suatu tindak pidana apakah perbuatan perbuatan terdakwa tersebut telah memenuhi dan sesuai dengan tindak pidana yang didakwakan oleh jaksa/penuntut umum. Dapat dikatakan lebih jauh bahwasanya pertimbanganpertimbangan yuridis ini secara langsung

\footnotetext{
${ }^{19}$ Firman. R. (1965) Analisis Kriminologis Kejahatan Penelantaran Bayi, Jurnal Fakultas Hukum Universitas Lampung, Bandar Lampung. Hlm 8.

20 http://www.miftakhulhuda.com, Ratio decidendi, diakses pada Senin, 27 November 2017, pukul 03.17 WIB.
}

akan berpengaruh besar terhadap amar/diktum putusan hakim. ${ }^{21}$

\section{Ratio Decidendi atau The Ground of} reason the decision merupakan pondasi penting yang juga mengikat. Karena putusan pidana berada di ranah hukum publik, maka bagian itu juga mengikat untuk publik atas dasar kepentingan umum (algemene belangen). ${ }^{22}$ Dapat pula disimpulkan bahwasanya ratio decidendi juga merupakan pertanggung jawaban hakim kepada masyarakat luas mengenai pemikirannya dalam memutus suatu perkara. Fungsi ratio decidendi adalah sebagai sarana mempresentasikan pokok-pokok pemikiran tentang problematika konflik hukum antara seseorang dengan orang lain, atau antara masyarakat dengan pemerintahan terhadap kasus-kasus yang menjadi kontroversi atau kontraproduktif untuk menjadi replika dan duplika percontohan, terutama menyangkut baik dan buruknya sistem penerapan dan penegakkan hukum, sikap tindak aparatur hukum, dan lembaga peradilan. ${ }^{23}$

\section{Putusan No.600/Pid.B/2011/PN.Lmj} tersebut adalah putusan dalam perkara tindak pidana penelantaran anak berjenis kelamin laki-laki berumur 1 (satu) hari dengan berat 2

\footnotetext{
${ }^{21}$ Mulyadi. L. (2014). Seraut Wajah Putusan Hakim Dalam Hukum Acara Pidana Indonesia, Perspektif, Teoritis, Praktik, Teknik Membuat dan Permasalahannya. Bandung : Citra Aditya Bakti. Hlm 219.

${ }^{22}$ Mertokusumo. S. (2009) Penemuan Hukum Suatu Pengantar. Yogyakarta : Liberty. Hlm 54.

${ }^{23}$ H.F Amos. A, (2007) Legal Opinion Teoritis \& Empirisme. Jakarta : Grafindo Persada. Hlm 34.
} 
UBELAJ, Volume 3 Number 1, April 2018 | 35

(dua) kg 3 (tiga) ons panjang 46 (empat terdakwa sudah mengakui semua puluh enam) $\mathrm{cm}$ yang dilakukan oleh perbuatannya. Menurut penulis Majelis Terdakwa Halimah Binti Dul Hamid, Alamat Hakim sebaiknya melihat juga dari sisi anak Dsn Kampung anyar Ds. Taman Asri, Kec. yang menjadi korban dari tindakan orang Ampel Gading, Kabupaten Malang.

Atas tindak pidana yang dilakukan oleh terdakwa berikut ini Jaksa/Penuntut umum memberikan dakwaan tunggal dengan Nomor Register Perkara: PDM463/LUMAJ/10/2011 tanggal 1 November 2011 yang mendakwa Terdakwa dengan Pasal 308 KUHP: "seorang ibu yang menaruh anaknya disuatu tempat supaya dipungut oleh orang lain tidak berapa lama sesudah anak itu dilahirkan oleh karena takut akan diketahui orang ia telah melahirkan anak atau dengan maksud akan terbebas dari pemeliharaan anak itu, meninggalkannya, maka hukuman maksimum yang tersebut dalam Pasal 305 dan Pasal 306 dikurangi sehingga seperduanya".

Putusan Pengadilan Negeri Lumajang Nomor. 600/Pid.B/2011/PN.Lmj tersebut yang hanya menjatuhkan pemidanaan selama 3 (tiga) bulan terhadap seorang perempuan yang telah membuang seorang anak yang baru saja dilahirkannya menurut hemat penulis merupakan putusan yang kurang bijak. Majelis Hakim pengadilan Negeri Lumajang dalam pertimbangannya hanya melihat dari sisi pelaku saja (terdakwa) yang berstatus sebagai janda sehingga menjadi tuanya yang tidak manusiawi. Anak tidak diberikan hak-hak nya sebagai sorang anak dan malah ditelantarkan begitu saja.

Putusan No.101/Pid.Sus/2015/PN. Bdw tersebut adalah putusan dalam perkara tindak pidana penelantaran bayi berjenis kelamin laki-laki berumur 1 (satu) hari dengan berat 2,3 (dua koma tiga) kg panjang 45 (empat puluh lima) cm, lingkar kepala 33 (tiga puluh tiga) $\mathrm{cm}$ yang dilakukan oleh Terdakwa Filda Umiatul Hasanah Binti Nurhasan, Alamat Desa Pakisan RT.006, RW. 001, Kecamatan Tlogosari, Kabupaten Bondowoso.

Atas tindak pidana yang dilakukan oleh terdakwa berikut dakwaan yang diajukan oleh Penuntut Umum pada Kejaksaan Negeri Bondowoso Atas tindak pidana yang dilakukan oleh terdakwa. Jaksa/Penuntut umum memberikan dakwaan Alternatif yang mendakwa Terdakwa dengan Pasal 77 huruf b Undang-Undang Nomor 35 Tahun 2014 tentang Perubahan atas Undang-Undang Nomor 23 Tahun 2002 Tentang Perlindungan Anak atau Pasal 307 KUHP atau Pasal 308 KUHP.

Majelis Hakim pada Pengadilan Negeri Bondowoso dalam perkara pembuangan bayi ini memberikan pertimbangan sebagai berikut:

tulang punggung keluarga dan bahwa 
1. Memperhatikan, Pasal 77 B UndangUndang RI No. 35 Tahun 2002 tentang Perlindungan Anak dan UndangUndang Nomor 8 Tahun 1981 tentang Hukum Acara Pidana serta peraturan perundang-undangan lain yang bersangkutan, MENGADILI:

a. Menyatakan Terdakwa Filda

Umiatul Hasanah Binti Nurhasan tersebut diatas, terbukti secara sah dan meyakinkan bersalah melakukan tindak pidana “menelantarkan anak';

b. Menjatuhkan pidana kepada terdakwa Filda Umiatul Hasanah Binti Nurhasan oleh karena itu dengan pidana penjara selama 1 (satu) tahun;

c. Menetapkan pidana penjara tersebut tidak perlu dijalani oleh Terdakwa melakukan perbuatan yang dapat dihukum sebelum lewat masa percobaan selama 1 (satu) tahun;

d. Menghukum pula kepada Terdakwa oleh karena itu dengan pidana denda sejumlah Rp. 1.000.000,00 (satu juta rupiah);

e. Menetapkan bahwa apabila pidana denda tersebut tidak dibayar, maka diganti dengan pidana kurungan selama 1 (satu) bulan;

f. Membebankan kepada Terdakwa membayar biaya perkara sejumlah Rp. 5.000 (lima ribu rupiah);
Pertimbangan hukum majelis hakim (ratio decidendi) dalam perkara tersebut diatas penulis merasa terdapat antinomi antara pasal yang didakwakan dengan pemidanaan yang dijatuhkan oleh majelis hakim. Padahal dalam hal ini penuntut umum mendakwa berdasarkan Undang-Undang Perlindungan Anak yang sudah barang tentu dikenal sebagai salah satu instrumen hukum yang digunakan untuk melindungi hak-hak anak. Karena anak adalah bagian yang tidak terpisahkan dari keberlangsungan hidup manusia dan keberlangsungan sebuah bangsa dan negara. Agar kelak mampu bertanggung jawab dalam keberlangsungan bangsa dan negara, setiap anak perlu mendapat kesempatan yang seluas-luasnya untuk tumbuh dan berkembang secara optimal, baik fisik, mental, maupun sosial.

Perubahan undang-undang Nomor 23 Tahun 2002 tentang Perlindungan Anak juga mempertegas tentang perlunya pemberatan sanksi pidana dan denda bagi pelaku kejahatan terhadap anak, untuk memberikan efek jera, serta mendorong adanya langkah konkret untuk memulihkan kembali fisik, psikis dan sosial anak korban dan/atau anak pelaku kejahatan. Hal tersebut perlu dilakukan untuk mengantisipasi anak korban dan/atau pelaku kejahatan di kemudian hari tidak menjadi pelaku kejahatan yang sama. ${ }^{24}$ Akan tetapi tujuan yang dicita-citakan oleh

${ }^{24}$ Penjelasan Uum atas Undang-Undang nomor 35 Tahun 2014 tentang Perubahan atas Undang-Undang Nomor 23 Tahun 2002 Tentang Perlindungan Anak. 
undang-undang tersebut akan sangat jauh dari yang diharapkan apabila dalam implementasinya tidak sesuai dengan amanat undang-undang tersebut. Majelis Hakim Pengadilan Negeri Bondowoso dalam putusan dalam perkara ini penulis merasa kurang cermat dan memahami asas-asas perlindungan anak. Bagaimana tidak, Majelis Hakim Pengadilan Negeri Bondowoso hanya menjatuhkan pemidanaan yang dalam Pasal 77 B UU No. 35 Tahun 2014 Tentang perlindungan Anak yang maksimal ancaman pidananya 5 (lima) tahun dan/atau denda paling banyak Rp. 100.000.000,00 (seratus juta rupiah), akan tetapi dalam perkara diatas hanya dijatuhi dengan pidana penjara selama 1 (satu) tahun dan denda sebesar Rp. 1.000.000,00.- (satu juta rupiah). Pertimbangan Majelis Hakim Pengadilan Negeri Bondowoso untuk memperingan pemidanaan didasarkan pada status terdakwa yang masih sebagai mahasiswa (masih terlalu muda) untuk menjalani suatu pemidanaan. Padahal tindak pidana dapat dilakukan tanpa memperhatikan batasan umur dan begitupula korban dari suatu tindak pidana tidak berbatas pada umur pula.

Putusan No. 164/Pid.B/2013/PN. Mjl tersebut adalah putusan dalam perkara tindak pidana penelantaran bayi berjenis kelamin laki-laki berumur 1 (satu) hari dengan berat 3 (tiga) $\mathrm{kg}$ panjang 49 (empat puluh sembilan) cm, yang dilakukan oleh Terdakwa Yayah Sartiah Binti Darman, Alamat Dusun Tengah
RT.014, RW. 004 Desa Sindanghaji, Kecamatan. Palasah, Kabupaten Majalengka. Atas tindak pidana yang dilakukan oleh terdakwa berikut dakwaan yang diajukan oleh Penuntut Umum pada Kejaksaan Negeri Majalengka Nomor Register Perkara: PDM163/MJLKA/07/2013 tanggal 11 Juli 2013 Atas tindak pidana yang dilakukan oleh terdakwa. Jaksa/Penuntut umum memberikan dakwaan tunggal Pasal 77 Huruf b Undang-Undang Nomor 23 Tahun 2002 Tentang Perlindungan Anak. Majelis Hakim pada Pengadilan Negeri Majalengka dalam perkara pembuangan bayi/penelantaran anak ini memberikan pertimbangan sebagai berikut:

1. Menimbang, bahwa berdasarkan keterangan saksi-saksi terdakwa telah melahirkan seorang anak hasil dari pemerkosaan dan yang menjadi korban pemerkosaan adalah terdakwa sendiri, sehingga untuk menutupi rasa malu tersebut terdakwa berniat untuk membuang anaknya dikarenakan terdakwa tidak mempunyai biaya dan orang yang tidak mampu karena terdakwa telah bercerai dari suaminya;

2. Mengingat dan memperhatikan hukum yang berlaku dan udang-undang yang bersangkutan khususnya Pasal 77 huruf b Undang-Undang Nomor 23 Tahun 2002 Tentang Perlindungan Anak, pasal-pasal dalam KUHP dan KUHAP serta pasal-pasal lain dan undang- 
undang yang bersangkutan, pada KUHP dan Peraturan Perundang-

\section{MENGADILI:}

a. Menyatakan bahwa terdakwa Yayah Sartiah Binti Darman telah terbukti secara sah dan meyakinkan bersalah melakukan tindak pidana "Penelantaran terhadap anak';

b. Menjatuhkan pidana kepada Terdakwa Yayah Sartiah Binti Darman oleh karena itu dengan pidana penjara selama 1 (satu) tahun dan denda sebesar Rp. 5.000.000,00.(lima juta rupiah) dengan ketentuan apabila denda tersebut tidak dibayar maka diganti dengan pidana kurungan selama 1 (satu) bulan;

c. Memerintahkan terdakwa tetap dalam tahanan;

d. Menetapkan masa penahanan yang telah dijalani oleh Terdakwa dikurangkan sepenuhnya dari pidana yang dijatuhkan;

e. Menetapkan barang bukti berupa: (terlampir) dikembalikan kepada Terdakwa Yayah Sartinah Binti Darman;

f. Membebankan kepada Terdakwa untuk membayar biaya perkara sebesar Rp. 1.000,00.- (seribu rupiah).

\section{Kesimpulan}

Hingga saat ini praktis instrumen hukum yang mengatur mengenai bayi belumlah dibuat, sehingga masih merujuk
Undangan lain yang terkait dengan anakanak, karena konsep bayi dan anak-anak memiliki persamaan yakni belum dewasa dan cakap hukum. Penelantaran dan pembuangan anak yang baru saja dilahirkan yang menyebabkan matinya anak tersebut, pelaku tindak pidana saat ini sebagian besar hanya dikenakan ketentuan pidana sebagaimana diatur dalam KUHP. Penelantaran anak dan pembuangan anak yang menyebabkan matinya anak dapat pula dikategorikan sebagai tindak pidana pembunuhan berencana sebagaimana diatur dalam ketentuan Pasal 340 KUHP, Pasal 341 KUHP. Dalam hal ini terdapat perbedaan yang sangat tipis mengenai perbedaan penelantaran anak yang baru dilahirkan dan pembuangan anak yang menyebabkan matinya anak. Penelantaran anak yang menyebabkan matinya anak tidak ada niat dari pelaku untuk membunuh anak yang dilahirkannya tersebut, berbeda dengan pembuangan anak, dimana pelaku memang sengaja membunuh anak yang baru dilahirkan tersebut.

Sanksi Pidana yang ada selama ini dalam persidangan tindak pidana penelantaran atau pembuangan anak yang menyebabkan kematian pada anak hanya terfokus pada KUHP saja dengan pemidanaan yang tidak berat. Sebagian besar hakim melalui contoh kasus yang ada memberikan pertimbangan bahwa pelaku 
tindak pidana melakukan hal tersebut karena keadaan malu dan sangat terpaksa karena sebelumnya mengandung dengan belum adanya perkawinan yang sah.

Adapun saran yang akan dikemukakan yakni harus dibuat pengaturan khusus diluar KUHP mengenai tindak pidana penelantaran dan pembuangan anak yang baru saja dilahirkan oleh orang tuanya karena selama ini belum adanya pengaturan khusus yang terkait mengenai hal tersebut. Agar tidak lagi terjadi kekosongan hukum (vacuum of norm).

Kepada Hakim pemeriksa perkara tindak pidana penelantaran dan pembuangan anak yang menyebabkan kematian dapat bertindak lebih tegas kembali kepada pelaku tindak pidana dengan mencoba tidak hanya menerapkan ketentuan hukum dalam KUHP sebagai dasar hukum pemidanaan. Selain itu karena penelantaran anak dan pembuangan anak yang baru saja dilahirkan dapat digolongkan sebagai tindak pidana pembunuhan berencana, hakim pemeriksa perkara dapat menjatuhkan pidana mati ataupun pidana seumur hidup bagi para pelaku tindak pidana.

\section{DAFTAR BACAAN}

Ancel, Marc (1965) Social Defence, A Modern Approuch To Criminal Problems, London, Routledge and Kegen Paul.

Arief, Barda Nawawi. (2005) Beberapa Aspek Kebijakan Penegakkan dan Pengembangan Hukum Pidana. Bandung : Citra Aditya Bakti.
Bruggink, .J.J.H. (1995) Rechtsreflecties, terjemahan Arief Sidharta. Bandung : Citra Aditya Bakti.

Firman, Riki. (2014) Analisis Kriminologis Kejahatan Penelantaran Bayi, Bandar Lampung : Jurnal Fakultas Hukum Universitas Lampung.

H.F, Abraham Amos. (2007) Legal Opinion Teoritis \& Empirisme, Jakarta : Grafindo Persada.

HS, Salim. (2013) Penerapan Teori Hukum Pada Penelitian Tesis dan Disertasi. Jakarta : Raja Grafindo Persada.

Hadjon, Philipus M. (1997) "Pengkajian Ilmu Hukum”. Surabaya : Paper Pelatihan Metode Hukum Normatif, Unair.

Hadjon, Philipus M. dan Tatiek Sri Djatmiati. (2005) Argumentasi Hukum, Yogyakarta : Gajah Mada University Press.

Hadidjah, Susi. (2008) Penegakkan Hukum Pidana Dalam Penanggulangan Pembunuhan Bayi di Wilayah DIY. Semarang : Tesis, Fakultas Hukum Universitas Diponegoro.

Hutchinson, Terry, (2002). Researching and Writing in Law. Sydney : Lawbook Co.

Koeswadji, Hermien Hadiati.(1984) Kejahatan Terhadap Nyawa, AsasAsas Kasus dan Permasalahannya. Surabaya : Sinar Widjaya.

Lamintang, P.A.F. (1985) Delik-Delik Khusus Kejahatan Terhadap Nyawa, Tubuh yang membahayakan bagi tubuh, nyawa. Bandung : Bina Cipta.

Marzuki, Peter Mahmud (2005) Penelitian Hukum. Jakarta : Prenada Media. 
Mertokusumo, Sudikno. (2009) Penemuan Hukum Suatu Pengantar. Yogyakarta : Liberty.

Muladi dan Barda Nawawi Arief (1998). Teori-Teori dan Kebijakan Pidana. Bandung : Alumni.

Mulyadi, Lilik. (2014). Seraut Wajah Putusan Hakim Dalam Hukum Acara Pidana Indonesia, Perspektif, Teoritis, Praktik, Teknik Membuat dan Permasalahannya. Bandung : Citra Aditya Bakti.

Rahardjo, Satjipto. (2002) Polri Sipil dan Perubahan Sosial di Indonesia. Jakarta : Kompas.

Saleh, Roeslan. (1983) Perbuatan Pidana dan Pertanggung Jawaban Pidana (Dua Pengertian Dasar Dalam Hukum Pidana). Jakarta : Aksara Baru.
Sianturi, S. R.(1983) Tindak Pidana Di KUHP Berikut Uraiannya. Bandung : Alumni.

Soekanto, Soerjono. (1983) Faktor-Faktor Yang Mempengaruhi Penegakkan Hukum. Jakarta : Raja Grafindo Persada.

Spinelli, Margaret. (2004) Maternal Infanticide Associated With Mental Illness; Prevention and The Promised of Saved Lives America Journal.

Sumiyanto. (2000) Pembunuhan Bayi Oleh Ibu Kandungnya Sendiri, Malang : Laporan Hasil Penelitian Universitas Brawijaya.

Tongat. (2003) Hukum Pidana Materiil Tinjauan Atas Tindak Pidana Terhadap Subyek Hukum Dalam Kitab Undang-Undang Hukum Pidana. Jakarta : Djambatan. 